\title{
HUKUM PERDATA INTERNASIONAL INDONESIA BIDANG HUKUM KELUARGA (FAMILY LAW) DALAM MENJAWAB KEBUTUHAN GLOBAL
}

Oleh:

\author{
Dr. Derita Prapti Rahayu, S.H., M.H.*
}

Email:

\begin{abstract}
In the current era of globalization and internationalization where economic, social and cultural developments have caused international relations to be infinite which can lead to civil disputes which give rise to the meeting of legal systems of countries in the world that have their own characteristics related to International Private Law. Hopefully there will not be many problems that arise if disputes over different citizenship civilizations are resolved through Alternative dispute resolution. Although when the Al forum decision on alternative dispute resolution was not carried out voluntarily by the parties affected by the execution, the execution of such decisions became the competence of the district court. Especially if the arbitration forum ruling was dropped outside Indonesia, then when the decision is to obtain recognition and execution within the jurisdiction of the Republic of Indonesia, the decision must first obtain an exequature from the Chair of the Central Jakarta District. Court. But the situation will be different if the dispute is not resolved through Alternative dispute resolution but is left to the court authorities to resolve it, it will be different.
\end{abstract}

Key word; Indonesian International Legal Law Family, The Global Needs, Indonesia

\section{A. PENDAHULUAN}

Manusia adalah makhluk social yang selalu hidup bermasyarakat yang pada dasarnya juga menimbulkan benturan-benturan kepentingan baik dalam ranah pidana maupun perdata. Sehingga muncul "Ubi societas, ibi ius." Maknanya, "Di mana ada masyarakat, di situ ada hukum." Ungkapan ini menunjukkan bahwa hukum pada dasarnya selalu muncul sejak pertama kali masyarakat itu ada, yang ditandai oleh pembenturan kepentingan-kepentingan. Itu baru pernyataan yang sederhana yaitu bahwa manusia adalah makhluk yang tidak bisa hidup diluar tatanan. Tetapi, ia tidak membicarakan kerumitan antara "societas" dan "ius" tersebut. Tidak tergambarkan bagaimana intensif dan rumit kaitan antara keduanya. ${ }^{1}$

Sehingga tidak bisa dipungkiri hukum selalu tertinggal dari fakta dalam pergaulan keperdataan.

\footnotetext{
*Dosen Tetap Fakultas Hukum Universitas Bangka Belitung.

${ }^{1}$ Satjipto Rahardjo, Biarkan Hukum Mengalir, Kompas, 2007, hlm. 9.
} 
Ketertinggalan hukum itu juga terjadi dalam ranah hukum acara perdata yang bahkan memunculkan anggapan bahwa proses beracara di Pengadilan dalam menyelesaikan sengketa keperdataan terlalu panjang.

Muncul fenomena dalam masyarakat, berupa pilihan forum untuk menyelesaikan konflik ke arah forum lain selain pengadilan. Apalagi untuk sengketa-sengketa yang melibatkan pihak-pihak multinasional. Para pihak multinasional bahkan sejak awal telah bersepakat di dalam kontrak mereka, manakala kelak terjadi konflik, maka penyelesaiannya tidak akan melalui pengadilan negeri. Menghadapi kenyataan itu, muncul "Alternative Dispute Resolution $(A D R)$ " sampai akhirnya Pemerintah Indonesia menerbitkan UndangUndang tentang Arbitrase dan Alternatif Penyelesaian Sengketa Nomor 30 Tahun 1999 sebagai salah satu upaya menjawab tuntutan dinamika masyarakat yang semakin kompleks.

Kiranya tidak akan ada banyak permasalahan yang timbul jika sengketa keperdataan baik warga Negara yang sama ataupun beda kewarganegaraan diselesaikan melalui ADR tersebut. Meskipun ketika putusan forum lain (ADR), tidak dilaksanakan secara sukarela oleh pihak yang terkena eksekusi, maka eksekusi putusan semacam itu menjadi kompetensi pengadilan negeri. Apalagi jika putusan forum arbitrase tadi dijatuhkan di luar Indonesia, maka ketika putusan hendak memperoleh pengakuan dan eksekusi di dalam wilayah hukum Republik Indonesia, terlebih dahulu putusan tersebut harus memperoleh exequatur dari Ketua Pengadilan Negeri Jakarta Pusat $^{2}$. Tapi keadaannya akan berbeda jika sengketa tersebut tidak diselesaikan melalui jalur ADR tetapi diserahkan pada otoritas pengadilan untuk menyelesaikannya, pasti akan berbeda.

\section{B. PEMBAHASAN}

1. Upaya Penyelarasan KaidahKaidah Hukum Perdata Internasional

Di masa globalisasi dan internasionalisasi saat ini dimana perkembangan ekonomi, sosial dan budaya telah menyebabkan pergaulan Internasional menjadi tak terbatas. Akibatnya batas-batas teritorial negara nasional hampir tidak lagi menjadipenghalang bagi

\footnotetext{
${ }^{2}$ Pasal 66 huruf d Undang-Undang Nomor 30 Tahun 1999 tentang Arbitrase dan Alternatif Penyelesaian Sengketa.
} 
berkembangnya ragam aktivitas manusia yang bisa menimbulkan sengketa keperdataan sehingga menimbulkan bertemunya sistemsistem hukum negara-negara di dunia yang mempunyai ciri khas tersendiri, misalnya;

"Sarah, merupakan seorang pengusaha berkewarganegaraan Inggris dan keturunan India. Sarah mengadakan perjanjian jual beli mobil dengan Beni, seorang pelajar berkewarganegaraan Indonesia yang sedang menjalankan studinya di Belanda. Perjanjian jual beli mobil tersebut dibuat di Indonesia dengan menggunakan bahasa Inggris. Setelah perjanjian ditandatangani, Sarah kemudian secara sepihak membatalkan perjanjian dan menjual mobil tersebut kepada orang lain. Beni yang tidak menerima perbuatan Sarah tersebut kemudian mengajukan gugatan ke Pengadilan Indonesia."

Atau...

"A merupakan warga negara Indonesia yang menikah dengan B, warga negara Inggris. Setelah menikah, A menjual tanahnya yang terletak di India kepada B. Perjanjian dibuat di Indonesia. 1 tahun kemudian, A hendak membatalkan perjanjian jual beli tersebut, karena berdasarkan hukum Indonesia perjanjian antara suami istri adalah dilarang. A mengajukan pembatalan di pengadilan India."

Contoh diatas sekedar menggambarkan kenyataan bahwa aturan hukum suatu Negara berdaulat sering dihadapkan pada masalah-masalah hukum yang ada kaitan dengan system hukum Negara lain. Jika kita melihat kenyataan ini, bisa kita simpulkan bahwa hal tersebut berkaitan dengan Hukum Perdata Internasional (HPI).

Hukum perdata internasional merupakan peraturan dan keputusan hukum yang menunjukkan stelsel hukum manakah yang berlaku atau apakah yang merupakan hukum jika hubungan-hubungan atau peristiwaperistiwa antara warga negara pada suatu waktu tertentu memperlihatkan titik pertalian dengan kaidah-kaidah hukum dari dua atau lebih negara yang berbeda dalam lingkungan kuasa, tempat, pribadi dan soal-soal. ${ }^{3}$
Sudarto Gautama dalam Bayu Seto
Hardjowahono, Dasar-Dasar Hukum Perdata 
Fungsi HPI hanya sebagai petunjuk dalam menentukan hukum mana yang harus diperlakukan, HPI tidak memberikan pemecahan pada persoalan hukum sampai pada materinya, HPI hanya menunjukkan pada hakim, hukum manakah yang harus dipakai, hukum manakah yang harus dipergunakan. Persoalan yang dihadapai hakim tidak diselesaikan dengan kaidah-kaidah HPI tapi diselesaikan menurut kaidah-kaidah hukum materiel yang telah ditunjuk oleh kaidah HPI.

Agar dapat diperoleh gambaran yang lebih konkret mengenai bagaimana logic dan keruntutan HPI dalam menyelesaikan persoalan hukum yang mengandung unsur asing, maka akan di gambarkan empat langkah berpikir hukum utama $\mathrm{HPI}^{4}$ :

a) Menghadapi persoalan hukum dalam wujud sekumpulan fakta hukum yang mengandung unsur asing (foreign element) hakim harus menentukan apakah perkara tersebut merupakan persoalan HPI beserta

Internasional, Bandung: Citra Aditya Bakti, 2006, hlm. 9.

${ }^{4}$ Ibid, hlm. 14-21. konsekuensinya (menentukan

titik taut primer). ${ }^{5}$

b) Penentuan ada/ tidaknya kompetensi/ kewenangan yurisdiksional forum untuk memeriksa, mengadili dan memutus perkara yang bersangkutan.

c) Menentukan sistem hukum intern negara mana/apa yang harus diberlakukan untuk menyelesaikan perkara/ menjawab persoalan hukum yang mengandung unsur asing (menentukan titik taut sekunder ${ }^{6}$ untuk menunjuk kearah lex causae).

d) Mencari dan menemukan kaidah HPI yang tepat melalui tindakan kualifikasi fakta dan kualifikasi hukum.

e) Menentukan kaidah HPI lex fori ${ }^{7}$ yang relevan dalam rangka penunjukan ke arah lex causae. $^{8}$

\footnotetext{
5 Titik taut primer adalah fakta dalam sebuah perkara HPI, mempertautkan perkara dengan wilayah suatu Negara asing. Ibid., hlm. 15.

6 Titik taut sekunder/titik taut penentu adalah fakta dalam perkara yang mendasarkan kaidah atau asas HPI dianggap bersifat menentukan (dominan) untuk digunakan dalam menentukan kea rah tempat yang hukumnhya harus diberlakukan sebagai lex causae, Ibid., hal. 17

${ }^{7}$ Lex fori adalah system hukum dari tempat dimana persoalan hukum diajukan sebagai perkara, Ibid., hal. 16

${ }^{8}$ Lex causae merupakan system hokum yang harus digunakan untuk menyelesaikan sebuah perkara HPI, Ibid.
} 
f) Memeriksa kembali fakta-fakta dalam perkara dan menentukan sistem hukum mana atau negara apa yang seharusnya diberlakukan sebagai lex causae.

g) Menyelesaikan perkara dengan menggunakan/ memberlakukan kaidah-kaidah hukum intern dari lex causae.

Jadi tugas HPI hanya mengenai pertanyaan tentang hukum mana yang harus diperlakukan. Setelah diketemukan, maka tugas HPI telah selesai dan kemudian tugas hakim adalah dengan menggunakan alat bukti yang ada menyelesaikan persoalan menurut ketentuanketentuan hukum bersangkutan.

Namun seandainya berdasarkan pendekatan HPI ternyata hukum asing yang seharusnya diberlakukan atau hak-hak asing yang harus ditegakkan dalam putusan perkara ternyata masih menjadi masalah. Hal ini berkaitan dengan apakah pengadilan suatu Negara selalu harus mengakui dan memberlakukan hukum asing tersebut atau tidak. Ada atau tidak dasar untuk menolak atau membenarkan proses hukum atau putusan pengadilan Negara lain, hal ini yang menjadi masalah mendalam dalam HPI, sehingga mncul usaha-usaha Negara-negara untuk melakukan upaya penyelarasan kaidah HPI.

Dari uraian di atas telah dapat kita simpulkan bahwa ada kemungkinan suatu Negara tidak mengakui atau menolak suatu proses peradilan dari Negara lain. Jika demikian, suka atau tidak, Indonesia begitu pula Negara lain harus terus melakukan upaya pembaharuan atas sejumlah perangkat norma hukum formal yang ada khususnya dalam hal ini dalam bidang hukum keperdataan yang mengandung unsur transnasional (HPI).

Mengadakan kesepakatan bilateral atau meratifikasi berbagai perjanjian internasional multilateral menyangkut HPI merupakan langkah yang tepat, apalagi di Indonesia belum ada kompilasi, apalagi unifikasi. Aturan HPI di Indonesia tersebar di berbagai peraturan perundang-undangan, misalnya Undang-Undang tentang Perkawinan, Undang-Undang tentang Kewarganegaraan dan sebagainya.

Seperti yang dilakukan oleh sejumlah Negara untuk mengatasi kesulitan tersebut meskipun upaya yang dilakukan itu bukan 


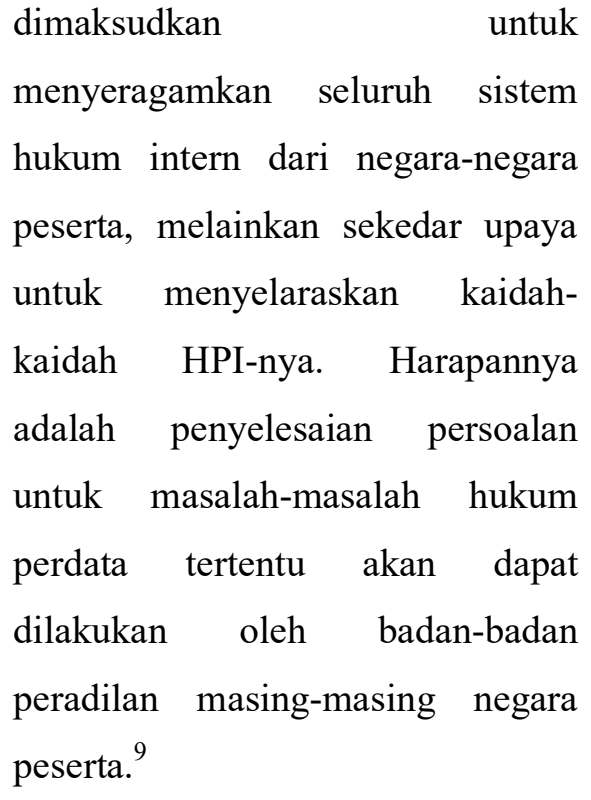

Upaya yang dilakukan sejumlah negara sejak akhir abad ke 19 melalui penyelenggaraan beberapa konperensi dalam bidang HPI yang diselenggarakan di Den Haag, untuk mempersiapkan unifikasi kaidah-kaidah HPI. Semula Konperensi Hukum Perdata Internasional (HPI) di Den Haag itu merupakan konperensi diplomatik antara negara-negara Eropa (negara-negara Eropa kontinental) dengan tujuan menjajagi kemungkinan mengadakan unifikasi kaidah-kaidah HPI. Akan tetapi kemudian pesertanya diperluas dengan masuknya Jepang (dari Asia tahun 1904). Kemudian seusai Perang Dunia ke II

9 Sudargo Gautama, Capita Selecta Hukum Perdata Internasional. Bandung: Alumni, 1983, hlm. 5. keanggotaan konperensi tersebut makin diperluas dengan masuknya Inggris (1951), Turki (1956), Israel dan RPA (1960), USA (1964), Canada (1968), dan kemudian diikuti pula oleh negara-negara dari kawasan Amerika Latin. ${ }^{10}$

Kemudian lebih lanjut di bentuklah HCPIL (Hague Conference on Private International Law) Indonesia hingga saat ini belum menjadi Negara pihak, Indonesia hanya menjadi Negara penandatangan atas beberapa konvensi. Beberapa contoh konvensi tersebut diantaranya ${ }^{11}$ :

a) Convention relating to Civil Procedure, 1954. (Konvensi tentang hukum acara perdata pada badan peradilan, tahun 1954).

b) Convention on the Service Abroad of Judicial and Extrajudicial Documents in Civil or Commercial Matters, 1965. (Konvensitentang penyampaian dokumen resmi badan peradilan kepadapara pihak yang berada di luar negeri di dalam perkara perdatadan

\footnotetext{
${ }^{10}$ Ibid., hlm. 6.

11 Sudargo Gautama, Indonesia dan KonvensiKonvensi Hukum Perdata Internasional. Bandung: Alumni, 2005
} 
dagang, tahun 1965). Konvensi ini pada dasarnya merupakan hasil revisi dari Bab pertama Konvensi 1954, yang dilakukan pada Konperensi Den Haag ke 10 tahun 1964.

c) The Hague Convention on the Recognition and Enforcement ofForeign Judgments in Civil and Commercial Matters, 1971.(Konvensi Den Haag tentang Pengakuan dan Pelaksanaan Putusan Hakim Asing di dalam perkara Perdata dan Dagang, tahun 1971).

Konvensi-konvensi di bidang Hukum Perdata Internasional tersebut mempunyai arti penting bagi Negara kita, terutama dalam iklim pemupukan komunikasi lalulintas internasional dan mempermudah hubungan menyelesaikan suatu perkara keperdataan berbeda kewarganegaraan.

\section{Asas-Asas Umum HPI Indonesia} Dalam Bidang Hukum Keluarga (Family Law)

HPI juga dipahami sebagai proses dan aturan-aturan yang digunakan oleh pengadilan untuk menentukan hukum mana yang harus diperlakukan dalam menghadapi perkara-perkara keperdataan yang bertalian dengan sistem hukum asing.Perkara keperdataan yang bertalian dengan sistem hukum asing tersebut antara lain meliputi ${ }^{12}$;

a) Subyek hukum.

b) Hukum perkawinan dan perceraian pasangan berbeda kewarganegaraan.

c) Hukum benda.

d) Pewarisan.

e) Perjanjian

\section{Asas-Asas HPI IndonesiaTentang} Subyek Hukum

a. Asas Nasionalitas

(Kewarganegaraan)

Stastus personal seseorang ditetapkan berdasarkan hukum kewarganegaraan (lex patriae) orang tersebut. Berdasarkan suatu asas dalam bidang hukum keperdataan yaitu asas mobilia sequntuur personam, asas pemberlakuan lex patriaeberlaku juga dalam penentuan status benda bergerak, maksudnya status benda bergerak ditetapkan berdasarkan hukum yang berlaku untuk menetapkan status

\footnotetext{
${ }^{12}$ Op.Cit. Bayu Seto Hardjowahono, hlm. 268-300
} 
personal orang yang memiliki benda tersebut.

Berdasarkan pasal $16 \mathrm{AB}$ dianut prinsip nasionalitas untuk status personal. Hal ini berati warga negara indonesia yang berada di luar negeri, sepanjang mengenai hal-hal yang terkait dengan status personalnya, tetap berada di bawah lingkungan kekuasaan hukum nasional indonesia, sebaliknya, menurut jurisprudensi, maka orang-orang asing yang berada dalam wilayah Republik indonesia dipergunakan juga hukum nasional mereka sepanjang hal tersebut masuk dalam bidang status personal mereka. Dalam jurisprudensi indonesia yang termasuk status personal antara lain perceraian, pembatalan perkawinan, perwalian anakanak, wewenang hukum, dan kewenangan melakukan perbuatan hukum, soal nama, soal status anak-anak yang dibawah umur.

b. Asas Domicilie

Status dan kewenangan
seseorang
ditentukan

c. Asas-asas untuk penentuan status badan hukum.

1) Asas kewarganegaraan/ domicilie pemegang saham

Status badan hukum ditentukan berdasarkan hukum dari tempat dimana mayoritas pemegang sahamnya menjadi warga negara (lex patriae) atau berdomisili (lex domicilie). Asas ini sudah banyak ditinggalkan karena kesulitan untuk menetapkan kewarganegaraan atau domisili dari mayoritas pemegang saham.

2) Asas centre of administration/business

Status dan kewenangan suatu badan hukum harus tunduk pada kaidah hukum dari tempat pusat kegiatan adiministrasi badan hukum tersebut.

3) Asas place of incorporation

Status dan kewenangan suatu badan hukum berdasarkan hukum dari tempat badan hukum secara resmi didirikan/dibentuk.

4) Asas centre of exploitation

Status dan kewenangan suatu badan hukum berdasarkan hukum dari tempat perusahaan itu memusatkan kegiatan operasional, eksploitasi atau kegiatan produksi barang/jasa 
d. Asas-Asas HPI Indonesia

Tentang Hukum perkawinan

dan perceraian pasangan

berbeda kewarganegaraan

Bidang hukum keluarga pada dasarnya mengatur tentang perkawinan dalam arti luas yaitu mencakup validitas materiil/formal perkawinan, keabsahan, akibat-akibat perkawinan, harta perkawinan dan berakhirnya perkawinan dalam HPI.

1) Validitas materiil perkawinan

a) Asas lex loci celebrationis, validitas materiil perkawinan ditetapkan berdasarkan kaidah hukum di tempat perkawinan diresmikan/dilangsungkan.

b) Asas yang menyatakan validitas materiil perkawinan berdasar sisterm hukum masingmasing pihak menjadi warga negara sebelum perkawinan.

c) Asas yang menyatakan validitas materiil perkawinan berdasar sisterm hukum masingmasing berdomisili sebelum perkawinan dilangsungkan.
2) Validitas formal perkawinan Validitas formal perkawinan ditentukan berdasarkan lex loci celebrationis

3) Akibat-akibat perkawinan

Beberapa asas HPI tentang akibat-akibat perkawinan seperti masalah hak dan kewajiban suami istri, hubungan orang tua dan anak, kekuasaan orang tua, harta kekayaan perkawinan adalah tunduk pada:

a) Sistem hukum tempat perkawinan di resmikan.

b) Sistem hukum dari tempat suami istri bersama-sama menjadi warga negara setelah perkawinan.

c) Sistem hukum dari tempat suami istri berkediaman tetap bersama setelah perkawinan atau tempat suami istri berdomisili tetap setelah perkawinan. Berdasarkan UU tentang kewarganegaraan anak yang lahir dari perkawinan seorang wanita WNI dengan pria WNA, maupun anak yang lahir dari perkawinan seorang wanita WNA dengan pria 


\begin{abstract}
WNI, sama-sama diakui sebagai warga negara Indonesia. Anak tersebut akan berkewarganegaraan ganda, dan setelah anak berusia 18 tahun atau sudah kawin maka ia harus menentukan pilihannya. Pernyataan untuk memilih tersebut harus disampaikan paling lambat 3 (tiga) tahun setelah anak berusia 18 tahun atau setelah kawin. ${ }^{13}$ Pemberian kewarganegaraan ganda ini merupakan terobosan baru yang positif bagi anak-anak hasil dari perkawinan campuran. $^{14}$
\end{abstract}

4) Perceraian dan akibat perceraian

Berdasarkan sistem hukum dari tempat :

a) Lex loci celebrationis

b) Joint nationality

\footnotetext{
${ }^{13}$ Pasal 4 huruf c, huruf $d$, huruf $h$, huruf I, Undang-Undang Republik Indonesia Nomor 12 Tahun 2006 tentang Kewarganegaraan Republik Indonesia

14 Perkawinan campuran adalah perkawinan antara dua orang yang di Indonesia tunduk pada hukum yang berlainan, karena perbedaan kewarganegaraan dan salah satu pihak berkewarganegaraan Indonesia. Pasal 57 UndangUndang Republik Indonesia Nomor 1 Tahun 1974 tentang Perkawinan
}

c) Joint residence/ domicilie

of choice setelah perkawinan

d) Diajukannya gugatan perceraian (lex fori)

Tampaknya asas Lex loci celebrationis dan lex fori merupakan asas yang paling cocok digunakan untuk mengatur perceraian dan akibatnya.

\section{e. Asas-asas HPI Indonesia}

\section{dalam hukum benda}

Sebelumnya harus ditetapkan mengenai klasisfikasi benda berdasarkan hukum dari tempat gugatan atas benda diajukan (lex fori) dan hukum dari tempat benda berada/terletak (lex situs).

\section{f. Asas-asas HPI Indonesia dalam hukum pewarisan}

1) Umumnya diterima asas bahwa dalam hal benda yang menjadi obyek pewarisan merupakan benda tetap, proses pewarisan atas benda berdasarkan hukum dari tempat benda berada/terletak.

2) Jika benda yang obyek waris adalah benda bergerak tunduk pada kaidah hukum waris dari tempat pewaris menjadi 
warga negara atau

berkediaman pada saat ia meninggal dunia.

3) Berkaitan dengan kecakapan pewaris dalam hal membuat testamen harus berdasarkan pada hukum dari tempat pewaris berdomisili atau menjadi warga negara pada saat pembuatan testamen atau hukum dari pewaris berdomisili/menjadi warga negara pada saat ia meninggal dunia.

\section{g. Asas-Asas HPI Indonesia}

\section{Dalam Hukum Perjanjian}

Asas HPI yang paling utama dalam hukum perjanjian antar warga negara lain adalah bahwa hukum yang dipilih dan disepakati oleh para pihak dalam perjanjian/kontrak. Namun dalam praktek, persoalan HPI menjadi lebih kompleks pada saat situasi dimana para pihak tidak melakukan pilihan hukum atau tidak menyatakan pilihan hukumnya secara tegas. Sehingga teori-teori HPI bidang kontrak sangat diperlukan atau lebih dikenal upaya menetapkan the proper law of contract. Di bawah ini akan ditinjau beberapa asas yang berkembang dalam HPI bidang hukum kontrak.

1. Asas

lex loci contractus/hukum tempat pembuatan kontrak.

2. Asas lex loci solutionis/hukum dari tempat pelaksanaan perjanjian.

3. Asas parti autonomy/kebebasan para pihak

Berkaitan dengan asas-asas HPI tentang perbuatan melawan hukum doktrin utama yang berkembang dalam HPI adalah:

1. Penentuan kualitas suatu perbuatan melawan hukum harus dilakukan berdasarkan hukum dari tempat perbuatan itu dilakukan.

2. Perbautan itu harus diatur berdasarkan hukum dari tempat timbulnya akibat dari perbuatan itu.

3. Bahwa penentuan kualitas suatu perbuatan sebaga perbuatan melawan hukum harus ditentukan oleh hukum forum termasuk penetapan hak dan tanggungjawab dari para pihak yang terlibat.

4. Berkaitan dengan point (c) ditentukan berdasarkan sistem hukum yang memiliki 


\begin{abstract}
kaitan paling signifikan dengan rangkaian tindakan dan situasi perkara yang sedang dihadapi.

5. Hukum yang berlaku untuk menyelesaikan suatu perkara harus ditetapkan setelah memperhatikan kebijakankebijakan umum dari negara yang hukumnya terlibat dalam perkara dan menganalisis kepentingankepentingan dari negara itu.
\end{abstract}

Contoh kasus:

Berdasarkan penjelasan di atas, maka akan kita ketahui bahwa dasar penentuan apakah suatu peristiwa masuk dalam kaidah HPI dan hukum mana yang akan digunakan sangat banyak dipengaruhi oleh apakah para pihak yang terlibat berkewarganegaraan berbeda/ asas kewarganegaraan (lex patriae) sehingga memberikan gambaran pada kita bahwa kejelasan status kewarganegaraan haruslah diprioritaskan bagi para pihak yang mempunyai hubungan keperdataan berbeda kewarganegaraan.
Sehubungan dengan hal itu bagi para pihak khususnya WNI yang mempunyai hubungan keperdataan berbeda kewarganegaraan seyogyanya segera mengajukann permohonan penetapan status kewarganegaraan sesuai dengan peraturan perundang-undangan yang berlaku. Seperti contoh berikut ini mengenai permohonan pendaftaran kewarganegaraan anak karena perkawinan beda kewarganegaraan orang tua yang ada di wilayah Kementerian Hukum dan HAM Propinsi Kepulauan Bangka Belitung.

\section{PERMOHONAN PENDAFTARAN KEWARGANEGARAAN ANAK KARENA PERKAWINAN BEDA KEWARGANEGARAAN ORANG TUA}

\section{KRONOLOGI}

1. Bahwa pada tanggal 02 bulan Januari tahun 2007 Saudara YUNITA ERAVIANTI, S.Ag, mengajukan permohonan pendaftaran kewarganegaraan anak berdasarkan pasal 41 Undang- Undang Kewarganegaraan Republik Indonesia Nomor : 12 Tahun 
2006

tentang

Kewarganegaraan Republik

Indonesia;

2. Bahwa permohonan tersebut diajukan

dikarenakan

perkawinan

dilakukan

berdasarkan

kewarganegaraan yang

berbeda, dimana suami dari

Ibu Yunita Eravianti

berkewarganegaraan

Thailand dan Ibu Yunita

Eravianti

berkewarganegaraan

Indonesia;

3. Bahwa permohonan diajukan dengan melampirkan persyaratan sebagai berikut:

a. Fotokopi kutipan akte kelahiran anak yang disahkan oleh pejabat yang berwenang atau Perwakilan Republik Indonesia;

b. Surat pernyataan dari orang tua atau wali bahwa anak belum kawin;

c. Fotokopi kartu tanda penduduk atau paspor orang tua anak yang masih berlaku yang disahkan oleh pejabat yang berwenang atau Perwakilan Republik Indonesia;

d. Pas foto anak terbaru berwarna ukuran 4x6 cm sebanyak 6 (enam) lembar;

e. Fotokopi kutipan akte perkawinan/buku nikah atau kutipan akte perceraian/surat talak/perceraian atau keterangan/kutipan akte kematian salah seorang dari orang tua anak yang disahkan oleh pejabat yang berwenang atau Perwakilan Republik Indonesia bagi anak yang lahir dari perkawinan yang sah;

f. Fotokopi kutipan akte pengakuan atau penetapan pengadilan tentang pengangkatan anak yang disahkan oleh pejabat yang berwenang atau Perwakilan Republik Indonesia bagi anak yang diakui atau yang diangkat;

g. Fotokopi kartu tanda penduduk warga negara asing yang disahkan oleh pejabat yang berwenang bagi anak yang sudah berusia 17 tahun dan bertempat tinggal di wilayah negara Republik Indonesia; dan

h. Fotokopi kartu keluarga orang tua yang disahkan oleh pejabat yang berwenang bagi anak yang belum wajib memiliki kartu tanda penduduk yang bertempat tinggal di wilayah Republik Indonesia.

Bahwa berdasarkan permohonan tersebut Kepada Kantor Wilayah Kementerian Hukum dan HAM Kepulauan Bangka Belitung meneruskan Permohonan kepada Menteri Hukum dan HAM RI di Jakarta; 


Bahwa setelah dilakukan
pemeriksaan dan penelitian
terhadap permohonan berkas
permohonan pendaftaran untuk
memperoleh kewarganegaraan
Republik Indonesia atas nama
Risal Farisi Toreyeh telah
memenuhi persyaratan
berdasarkan UU Tentang
kewarganegaraan, Peraturan
Menteri Hukum dan HAM RI
Nomor : M.01-HL.03.01 Tahun
2006 tentang tentang tata cara
pendaftaran untuk memperoleh
kewarganegaraan
berdasarkan pasal 41 ,sehingga
dikabulkan oleh Menteri Hukum
dan HAM RI

\section{PENUTUP}

Upaya penyelarasan kaidah-kaidah Hukum Perdata Internasional di Indonesia degnan menjadi Negara penandatangan atas beberapa konvensi. Beberapa contoh konvensi tersebut diantaranya:

1. Convention relating to Civil Procedure, 1954. (Konvensi tentang hukum acara perdata pada badan peradilan, tahun 1954).

2. Convention on the Service Abroad of Judicial and Extrajudicial Documents in Civil or Commercial Matters, 1965. (Konvensitentang penyampaian dokumen resmi badan peradilan kepadapara pihak yang berada di luar negeri di dalam perkara perdatadan dagang, tahun 1965). Konvensi ini pada dasarnya merupakan hasil revisi dari Bab pertama Konvensi 1954, yang dilakukan pada Konperensi Den Haag ke 10 tahun 1964.

3. The Hague Convention on the Recognition and Enforcement of Foreign Judgments in Civil and Commercial Matters, 1971. (Konvensi Den Haag tentang Pengakuan dan Pelaksanaan Putusan Hakim Asing di dalam perkara Perdata dan Dagang, tahun 1971).

Asas-Asas Umum HPI Indonesia Dalam Bidang Hukum Keluarga (Family Law) Asas Nasionalitas (Kewarganegaraan), asas domisili, Asas centre of administration/business, Asas place of incorporation, Asas centre of exploitation, Lex loci celebrationis, Joint nationality, Joint residence/ domicilie of choice setelah perkawinan, Diajukannya gugatan perceraian (lex fori). 


\section{DAFTAR PUSTAKA}

Bayu Seto Hardjowahono, DasarDasar Hukum Perdata Internasional, Bandung: Citra Aditya Bakti, 2006.

Satjipto Rahardjo, Biarkan Hukum Mengalir, Kompas, 2007.

Sudargo Gautama, Capita Selecta Hukum Perdata Internasional. Bandung: Alumni, 1983.

Sudargo Gautama, Indonesia dan konvensi-konvensi hukum perdata internasional.Bandung: Alumni, 2005.

Undang-Undang Republik Indonesia Nomor 1 Tahun 1974 Tentang Perkawinan.

Undang-Undang Nomor 30 Tahun 1999 tentang Arbitrase dan Alternatif Penyelesaian Sengketa.

Undang-Undang Republik Indonesia Nomor 12 Tahun 2006 Tentang Kewarganegaraan Republik Indonesia 